\title{
PRIMARY, NEW AND EXPORT PRODUCTION IN THE NW PACIFIC SUBARCTIC GYRE DURING THE VERTIGO K2 EXPERIMENTS
}

M. Elskens ${ }^{1}$, N. Brion ${ }^{1}$, K. Buesseler ${ }^{2}$, B.A.S. Van Mooy ${ }^{2}$, P. Boyd ${ }^{3}$, F. Dehairs ${ }^{1}$, N. Savoye ${ }^{4}$ and W. Baeyens ${ }^{1}$

1. Department of Analytical and Environmental Chemistry, Vrije Universiteit Brussel, Pleinlaan 2, B-1050 Brussels, Belgium

2. Department of Marine Chemistry and geochemistry, Woods Hole Oceanographic Institution, Massachusetts, 02543, USA

3. NIWA Centre for Physical and Chemical Oceanography, Department of Chemistry, University of Otago, Dunedin, New Zealand

4. Observatoire Aquitain des Sciences de I'Univers, UMR EPOC, Université Bordeaux 1 CNRS, Station Marine d'Arcachon, 2 rue du Pr. Jolyet, Arcachon, France

\begin{abstract}
This paper presents results on tracer experiments using ${ }^{13} \mathrm{C}$ and ${ }^{15} \mathrm{~N}$ to estimate uptake rates of dissolved inorganic carbon (DIC) and nitrogen (DIN). Experiments were carried out at station $\mathrm{K} 2\left(47^{\circ} \mathrm{N}, 161^{\circ} \mathrm{E}\right)$ in the NW Pacific subarctic gyre during July-August 2005. Our goal was to investigate relationships between new and export production. New production was inferred from the tracer experiments using the $f$ ratio concept $(0-50 \mathrm{~m})$; while export production was assessed with neutrally buoyant sediment traps (NBSTs) and the $e$ ratio concept (at $150 \mathrm{~m}$ ). During trap deployments, K2 was characterized both by changes in primary production (523 to 404 $\mathrm{mg} \mathrm{C} \mathrm{m} \mathrm{m}^{-2}$ ), new production (119 to $67 \mathrm{mg} \mathrm{C} \mathrm{m}^{-2} \mathrm{~d}^{-1}$ ), export production (68 to $24 \mathrm{mg}$ $\mathrm{C} \mathrm{m}^{-2} \mathrm{~d}^{-1}$ ) and phytoplankton composition (high to low proportion of diatoms). The data indicate that 17 to $23 \%$ of primary production is exportable to deeper layers ( $f$ ratio) but
\end{abstract}


only 6 to $13 \%$ collected as a sinking particle flux at $150 \mathrm{~m}$ (e ratio). Accordingly, $>80 \%$ of the carbon fixed by phytoplankton would be mineralized in the upper 50m $(1-f)$, while $<11 \%$ would be within $50-150 \mathrm{~m}(f-e)$. DIN uptake flux amounted to $0.5 \mathrm{mM} \mathrm{m}^{-2}$ $\mathrm{h}^{-1}$, which was equivalent to about $95 \%$ particulate nitrogen (PN) remineralized and/or grazed within the upper $150 \mathrm{~m}$. Most of the shallow PN remineralization occurred just above the depth of the deep chlorophyll maximum (DCM), where a net ammonium production was measured. Below the DCM, while nitrate uptake rates became negligible because of light limitation, ammonium uptake did continue to be significant. The uptake of ammonium by heterotrophic bacteria was estimated to be $14-17 \%$ of the DIN assimilation. Less clear are the consequences of this uptake on the phytoplankton community and biogeochemical processes, e.g. new production. It was suggested that competition for ammonium could select for small cells and may force large diatoms to use nitrate. This implies that under Fe stress as observed here, ammonium uptake is preferred and new production progressively suppressed despite the surplus of nitrate. .

\section{Introduction}

Early approaches to investigate the efficiency of particle export between the surface and subsurface ocean were restricted to surface waters and deep-ocean processes (Pace et al., 1987) leading to the introduction of the new production paradigm. "The sinking flux of particulate organic carbon in the deep ocean is quantitatively equivalent to the organic matter that can be exported from the total production in the euphotic zone without the production system running down" (Eppley and Peterson, 1979). This concept is one of the cornerstones of biogeochemistry since it constrains both the sustainable exploitation of marine resources and the role of the oceans in the regulation of excess anthropogenic $\mathrm{CO}_{2}$ accumulation in the atmosphere (Longhurst and Harrison, 1989). New production is merely defined as the portion of primary production driven by externally supplied nutrients (where external refers to sources outside the euphotic zone including upwelling, atmospheric deposition and nitrogen fixation). The resulting ratio of new to total primary production is called the $f$ ratio. The determination of ${ }^{15} \mathrm{~N}$ nitrogen uptake enables the 
separation of new from regenerated production - i.e. of primary production sustained by nitrate and $\mathrm{N}_{2}$ from that sustained by regenerated $\mathrm{N}$-nutrients such as ammonium and amino acids (Dugdale and Goering 1967). Assuming a steady state nutrient budget for the upper ocean and an absence of nitrate regeneration in the euphotic zone, Eppley and Peterson (1979) have linked new production to export production via the use of $f$ ratio. Although the concept of $f$ ratio is simple, its estimation can be rather complicated, and has been controversial (Eppley, 1989, Platt et al., 1992; Bronk et al., 1994, Yool et al., 2007). For example, the production of dissolved organic nitrogen during ${ }^{15} \mathrm{~N}$ uptake experiments, the downward advection and diffusion of dissolved organic matter may bias estimates of new production and its relation with the export of organic particles from the trophogenic zone. However, no other current techniques can yield comparable data on nitrogen flux, and new production should better be regarded as "exportable production" rather than "export production" (see Sambrotto and Mace, 2000, Reuter et al., 2007). Alternatives to ${ }^{15} \mathrm{~N}$ new production assessment have since been proposed, e.g., sediment traps at the base of the photic zone and the thorium-uranium disequilibria, but these methods have their own drawbacks (Buesseler et al., 2006; Buesseler et al. 2007b). The VERTIGO (VERtical Transport In the Global Ocean) research project overcame many of the issues of trap collection biases in mesopelagic waters by using Neutrally Buoyant Sediment Traps (NBST). These traps are designed to sink to predetermined depths via accurate ballasting and to drift along with the prevailing current, thereby avoiding problems related with flow perturbation typical for bottom and surface tethered traps (Buesseler et al., 2007b, and references therein).

The specific objective of this paper is to investigate relationships between new (potential carbon/nitrogen export flux from the photic zone) and export productions (sinking flux of particulate organic carbon/nitrogen POC/PN collected at the base of the photic zone). New production was inferred from ${ }^{15} \mathrm{~N}$ tracer experiments using the traditional definition of $f$ ratio; while export production was assessed with neutrally buoyant sediment traps (NBSTs) and the $e$ ratio concept, that is the measured $150 \mathrm{~m}$ POC flux to primary production ratio. Our ultimate goal is to determine how much of the carbon and nitrogen 
assimilated by phytoplankton is mineralised in the trophogenic zone, hence providing an estimate of the potential supply of organic matter to the twilight zone, a dim region 100 to $1000 \mathrm{~m}$ below the surface, where the attenuation in particle flux $v s$. depth is particularly pronounced.

\section{Methods}

\subsection{Site description}

$\mathrm{K} 2\left(47^{\circ} \mathrm{N}, 161^{\circ} \mathrm{E}\right)$ is a mesotrophic site in the NW Pacific subarctic gyre, characterized by high surface nutrients, including silica, and a clear dominance of the phytoplankton community by diatoms (Honda, 2003; Honda et al., 2006; Buesseler et al., 2008, this volume). There is significant annual variability in surface chlorophyll, ranging from 0.1 to $0.8 \mathrm{mg} \mathrm{m}^{-3}$ and possibly higher with great small-scale variability (see Figure 2 in Buesseler et al., 2008, this volume). There is also apparent and variable drawdown of macronutrients as the season progresses (see Table 1 in Buesseler et al., 2008, this volume).

As determined from SeaWIFS images (Honda and Watanabe, 2007), we arrived at K2 in 2005 about 20-30 days after the seasonal maximum in phytoplankton biomass, and prior to a slightly smaller autumn bloom. The $150 \mathrm{~m}$ POC flux data show a significant drop off during the cruise reflecting the termination of a diatom bloom, and is echoed in the record from deep moored traps (Buesseler et al., 2007a). As a result biogenic silica appears to be the major constituent of trapped material with $80 \%$ by weight being opal (Buesseler et al., 2007a, Lamborg et al., 2008, this volume).

\subsection{The tracer experiments}

The design of experiments for the simultaneous determination of inorganic carbon and nitrogen uptake rates involved the addition of enriched ${ }^{15} \mathrm{~N}$ (as $\mathrm{NH}_{4} \mathrm{Cl}, \mathrm{KNO}_{3}$ and $\mathrm{N}_{2}$ ) and ${ }^{13} \mathrm{C}$ substrates (as $\mathrm{Na}_{2} \mathrm{CO}_{3}$ ) to water samples, and after some period of incubation measuring the ${ }^{15} \mathrm{~N}$ and ${ }^{13} \mathrm{C}$ incorporated into particulate material. Seawater was sampled using Niskin bottles at four depths ( 10, 20, 40, 50m). The changes in substrate 
concentrations and abundances of the particulate pools were measured just after spiking, and after 3 incubation times ( 2, 4, 6 hours). The kinetic experiments were conducted on deck in a simulated in situ light (4 levels from $100 \%$ to $1 \%$ of the surface irradiance tuned with appropriate neutral density screens) and temperature controlled incubator. The sampling was repeated 8 times during trap deployments D1 (30/07 to 07/08/2005; CTD biocasts $18,23,31,39)$ and D2 (10/08 to 18/08/2005; CTD biocasts $62,66,76,84)$ providing a total of about 500 tracer experiments. Full CTD and bottle data are available on line at http://ocb.whoi.edu/vertigo.html. Map of drifting sediment trap trajectories, deployment and retrieval sites for NBSTs and locations of biocast CTD stations are shown in Figure 6 of Buesseler et al. (2008, this volume). In the experimental set up the initial abundance of the substrate pools was calculated with an isotope dilution law (Harrison, 1983). Tracer additions were variable ranging from 1 to $14 \%$ of the ambient substrate pools as shown in Table 1. Dark bottles incubations for carbon and nitrogen uptakes were also performed with water samples collected at $70 \mathrm{~m}$.

\subsection{Analytical procedures}

Ammonium concentrations were determined manually aboard ship with the Berthelot

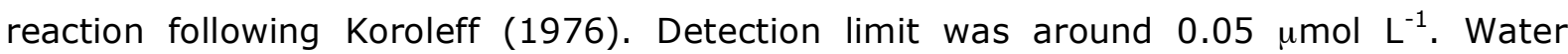
samples for the determination of nitrate and nitrite were filtered through cellulose membranes (Millipore type Millex-HA, 0,45 $\mu \mathrm{M}$ ) stored in polyethylene bottles and frozen until analysis in the home laboratory with a Technicon Auto-Analyser II. The procedure involved the reduction of nitrate to nitrite on a $\mathrm{Cu}-\mathrm{Cd}$ column, and the subsequent determination of nitrite with the Griess reaction following Hansen and Grasshof (1983). Detection limit was around $0.1 \mu \mathrm{mol} \mathrm{L} \mathrm{L}^{-1}$. Particulate nitrogen and carbon were collected by filtration ( $1 \mathrm{~L}$ ) on combusted GF/F glass-fibre (Whatman) after each time-step. The filters were dried at $50^{\circ} \mathrm{C}$ for 8 hours and pre-treated with $\mathrm{HCl}$ acid vapour to remove carbonates prior analysis of PN and $\mathrm{POC}$ concentration along with their ${ }^{15} \mathrm{~N}$ and ${ }^{13} \mathrm{C}$ abundances. In all cases, the abundances and concentration of the particulate matter were measured using an elemental analyzer (Carlo-Erba $\mathrm{C} / \mathrm{N}$ analyzer) coupled via a 
conflo-interface to an isotope ratio mass spectrometer Finnigan Delta-Plus $\mathrm{XL}$ (Nieuwenhuize et al. 1994). Standard deviations on concentrations and isotopic ratios are based on long-term within-laboratory reproducibility estimates. For nitrate and ammonium determinations, relative standard deviation (RSD) are variable ranging from 2 to $15 \%$ (D'Ellia, 1983, and references therein). For particulate materials, Nieuwenhuize et al. (1994) reported RSD values close to $4 \%$. For isotope analysis, results obtained during collaborative studies on enriched ${ }^{15} \mathrm{~N}$ (IAEA-311) and ${ }^{13} \mathrm{C}($ IAEA-309B) reference materials indicated RSD less than $0.5 \%$. However, actual precision may be lower than the quoted value, particularly with enriched sample that has been processed through all steps of the incubation protocol. In our laboratory RSD on ${ }^{13} \mathrm{C}$ and ${ }^{15} \mathrm{~N}$ enrichment are less than $5 \%$ for replicate measurements (Elskens et al., 2005).

\subsection{Bacterial production and carbon demand}

Bacterial production (BP) was determined using $\left[\right.$ methyl- $\left.{ }^{3} \mathrm{H}\right]$-thymidine (TdR) incorporation incubations conducted at atmospheric pressure and in situ temperatures (Fuhrman and Azam, 1982). Triplicate, acid-washed $30 \mathrm{~mL}$ polycarbonate bottles were filled with seawater from each depth and spiked with $20 \mathrm{nmol} \mathrm{L}^{-1}$ of TdR. Replicate incubations were poisoned with 3\% formaldehyde prior to addition of TdR. All bottles were incubated for 24 hours. TdR incorporation rates were determined following trichloroacetic acid precipitation and filtration as described by Carlson et al. (1996). BP was calculated from TdR incorporation rates using TdR conversion factors of $1-2 \times 10^{18}$ cells $\mathrm{mol}^{-1}$ and a carbon conversion factor of $15 \mathrm{fg} \mathrm{C}^{-1}{ }^{-1}$; these values approximate the median of those published for bacterial communities in surface waters (Ducklow, 2000 and references therein). Bacterial carbon demand (BCD) was calculated using a bacterial growth efficiency (BGE) ranged between 0.10 and 0.15 , which was also derived from published values for surface bacterial communities (del Giorgio and Cole, 2000).

\subsection{Neutrally buoyant sediment trap (NBST)}

NBST trap was deployed at $150 \mathrm{~m}$ for primary flux measurement. Briefly, NBST is a free vehicle that sinks to a preprogrammed sampling depth for 3-5 day deployments and 
drifts with local currents, thus minimizing possible hydrodynamic biases (Buesseler et al., 2007b, and references therein). Detailed descriptions of the NBST methodology along with protocols for blanks, swimmer removal, sample preservation and sampling handling and analytical methods are presented in Lamborg et al. (2008, this volume).

\subsection{Calculation of nitrogen and carbon uptake}

The most widespread ${ }^{15} \mathrm{~N}$ and ${ }^{13} \mathrm{C}$ model is derived from the isotopic and mass balances in the particulate fraction providing the commonly used formula (Eq. 1) for nitrogen and carbon uptakes (Dugdale and Goering, 1967, Legendre and Gosselin, 1996):

$$
\frac{A E P(t) \cdot P(t)}{A E S(i)}=U(t) \cdot t
$$

where $Æ P(t)$ stands for the ${ }^{15} \mathrm{~N}$ or ${ }^{13} \mathrm{C}$ atom\% excess in the particulate matter at time $\mathrm{t}$, ES(i) is the initial ${ }^{15} \mathrm{~N}$ or ${ }^{13} \mathrm{C}$ atom\% excess of the substrate pool, $\mathrm{P}(\mathrm{t})$ the POC or $\mathrm{PN}$ concentration at time $\mathrm{t}$ and $\mathrm{U}(\mathrm{t})$ the nitrogen or carbon uptake rate.

Plotting the left term of Eq. (1) as a function of time does not necessarily result in a straight-line with a near zero intercept and a constant slope $U(t)$ (Figure 1 ). The departure to linearity (the fall-off in the reaction rate) is due to isotope dilution and tracer release during incubation (Elskens et al., 2005 and references therein). Therefore, the choice between straight line and curvilinear regression methods is made using a Mandel's fitting test (Mandel, 1964). In these regressions, the initial rate, $U$ at $t=0$ is given by the first order coefficient and yield an estimate of gross uptake rate with unit $\mu \mathrm{M} \mathrm{h}^{-1}$. This procedure facilitates data treatment and model analysis because it does not require any assumption about rate law expression (see however section 2.7 ). Overall the precision on uptake estimates averaged $5-18 \%$ (Table 1). From Eq. (1) one also estimate a detection or decision limit for the uptake rate according to the IUPAC recommendations (Currie, 1995):

$$
D L=3 \cdot \sqrt{2} \cdot s d_{\alpha n}
$$

where $s d_{a n}$ is the standard deviation of the natural background value. 
$\mathrm{DL}$ is defined as the critical level or decision limit above which an observed signal $Æ P(t)$ may be reliably recognised as detected. It amounts to 0.017 and 0.008 atom $\%$ for ${ }^{13} \mathrm{C}$ and ${ }^{15} \mathrm{~N}$, respectively. For that reason all $Æ P(t)$ below $D L$ will provide uptake rates, which are not significantly different from 0 (Table 1 ).

Daily primary production was obtained by multiplying the hourly ${ }^{13} \mathrm{C}$ data (see above) by the day light period. These values assumed to represent the net primary production (NPP) were not corrected for dark uptake since the latter was below detection. The total euphotic zone NPP ( $\mathrm{mg} \mathrm{C} \mathrm{m}^{-2} \mathrm{~d}^{-1}$ ) was assessed using the trapezoid rule and integrated to $\sim 55 \mathrm{~m}$, the depth of the $0.1 \%$ light penetration. A comparison between NNP data obtained with ${ }^{13} \mathrm{C}$ and ${ }^{14} \mathrm{C}$ (Boyd et al., this issue) techniques are discussed below in the text. For nitrogen daily values were not calculated. Depending on length of incubation, different cellular metabolic processes may be measured (Glibert and Capone, 1993). Therefore, gross uptake as determined here is probably less ambiguous to consider (Elskens et al., 2005). The total euphotic zone nitrogen based production UDIN ( $\mathrm{mM} \mathrm{m}^{-2}$ $\mathrm{h}^{-1}$ ) was integrated as described above. We estimate the bacterial uptake of inorganic nitrogen using the formula introduced by Kirchman (1994):

$\% \mathrm{~N}-$ uptake $=1.4 \cdot \frac{B P}{N P P}$

where BP and PP are the bacterial and net primary production, respectively and $1.4 \mathrm{a}$ correction factor taking into account differences in $\mathrm{C} / \mathrm{N}$ ratios between phytoplankton and bacteria. Since nitrate uptake by heterotrophic bacteria is usually low, it can be safely ignored as a first approximation (Kirchman, 1994). Eq. (3) gives thus an estimate of the bacterial ammonium uptake.

\subsection{Calculation of nitrogen regeneration}

Compartmental model analysis was used to assess nitrogen regeneration (ammonification and nitrification rates). The three compartment open model depicted in Figure 2 is similar to the generic models described in Elskens et al. (2002) and (2005), 
and assumes that exchange between compartments is governed by first order differential equations with constant coefficients of the general type:

$$
\frac{d X_{i}}{d t}=\sum_{j \neq i}^{n} k_{j} \cdot X_{j}-\sum_{i \neq j}^{n} k_{i} \cdot X_{i}
$$

where $\mathrm{X}$ are the nitrogen isotopes $\left({ }^{15} \mathrm{~N}\right.$ or $\left.{ }^{14} \mathrm{~N}\right)$ in compartment $\mathrm{i}$ at time $\mathrm{t}, \mathrm{k}$ is the rate constant for transport between compartments (in reciprocal time units).

With uptake rates being determined, the remaining parameters to be optimized are $R_{A}$, $\mathrm{kr}_{\mathrm{N}}$ and $\mathrm{kl}_{\mathrm{p}}$ (Figure 2). The mass balance differential equations (Eq. 4) are solved numerically (Elskens et al. 1988) and optimization achieved using weighted least squares techniques. Statistical inferences about parameter values and model outcomes are performed as described in Elskens et al. (2005) and (2007) (see also section 2.8).

\subsection{Quality control analysis}

Optimal tracer addition, considered as $<10 \%$ of the ambient substrate concentration (Dugdale and Goering, 1967) was nearly always achieved (Table 1), and thus one can consider that in situ rates of uptake have been addressed in this study (Glibert and Capone, 1993). Uncertainty on uptake and regeneration represents the propagation of random errors through rate calculations. It can be seen from Eq. (5) that the relative standard uncertainty (RSU) on uptake is not much larger than the largest relative standard deviation used to calculate it.

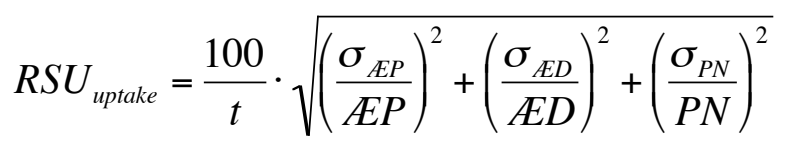

As a corollary to this, when a tracer addition much less than $10 \%$ of ambient is made such as for nitrate, the atom $\%$ excess in the particulate fraction ÆEP is very small, its relative standard deviation increases and $\mathrm{RSU}_{\text {uptake }}$ dramatically rises (Table 1 ). Despite optimal tracer additions for $\mathrm{N}_{2}$, ÆEP remained below DL (Eq. 2) and thus the rates were insignificant ( $<$ Method Detection Limit or MDL). This probably results from the fact that $\mathrm{N}_{2}$ fixation (i) is not energetically favourable when ammonium is available, and (ii) 
requires nearly 100 times more iron than any other means of nitrogen assimilation (Falkowski, 1997; Orcutt et al., 2001) while K2 is apparently iron-limited (Boyd et al., this issue). Finally the best conditions were encountered during the carbon and ammonium assimilation experiments with RSU values of 5 to $8 \%$ (Table 1 ). In contrast herewith, solutions for regeneration rates cannot be expressed explicitly, and are sought with an iterative method (Marquardt-Levenberg algorithm). The standard error on the regression coefficient was assessed using Variance-Covariance matrix as described in de Brauwere et al., (2005a). A $t$ statistic ( $t$ is the ratio of the regression coefficient to its standard error) is computed to test whether the estimated parameter is significant. For nitrate the $t$ test indicated that the rate constant $\mathrm{kr}_{\mathrm{N}}$ could be removed from the model regression without affecting the goodness of fit meaning that $\mathrm{RNO}_{3}$ rates were insignificant ( $<\mathrm{MDL}$, Table 1). For ammonium, the RSU on $\mathrm{RNH}_{4}$ was in the order of $23 \%$. The accuracy of the model outcome (goodness of fit or agreement between the observations and the model counterparts) is tested with a $\chi^{2}$ statistic. When the sum of the weighted least squares residuals falls within the $95 \%$ confidence limit of a $\chi^{2}$ distribution, the model results is regarded as being satisfactory (de Brauwere et al., 2005b). We make a distinction between variability and uncertainty. This dichotomy has become conventional in environmental assessments (Sutter, 2007). Variability is an intrinsic property of the system and covers changing environmental conditions and sampling heterogeneity. It ranges from 14 to $35 \%$ (Table 1 ).

\section{Results and discussion}

\subsection{Surface euphotic zone}

The surface mixed-layer (ML) was estimated for every biological cast during trap deployments. Map of drifting sediment trap trajectories, deployement and retrieval sites for NBSTs and locations of biocast CTD stations are shown in Figure 6 of Buesseler et al. (2008, this volume). Generally a well-defined thermocline was present, showing a shallow $25 \mathrm{~m}$ summer time $\mathrm{ML}$ above the temperature minimum of $<2{ }^{\circ} \mathrm{C}$ near $100 \mathrm{~m}$ (Figure 3). The limit of the euphotic zone, defined as equal to the depth of $0.1 \%$ light 
penetration was estimated around $55 \mathrm{~m}$, and coincided roughly with the depth of the deep chlorophyll maximum (DCM). Nitrate concentrations remained high, greater than 13 $\mu \mathrm{M}$ in the upper $\mathrm{ML}$, increasing up to $\sim 30 \mu \mathrm{M}$ near $100 \mathrm{~m}$. Ammonium concentration peaked at $>1.5 \mu \mathrm{M}$ just above the DCM, and was shallower than the nitrite maximum observed just below the DCM (Figure 3).

While the nitrate and nitrite stocks did not change significantly between trap deployments (D1 and D2), a build-up of ammonium was found in the first 10 days of sampling with a net production rate of $3.2(\mathrm{SE}=0.4) \mathrm{mmol} \mathrm{m}^{-2} \mathrm{~d}^{-1}$ (Figure 4). Suspended organic carbon and nitrogen followed exponential type decay $v s$. depth in the euphotic zone with $\mathrm{C} / \mathrm{N}$ ratios closed to Redfield. Both particulate stocks decreased almost linearly throughout sampling with net consumption rates of 0.95 (SE $=0.15$ ) $\mathrm{mmol} \mathrm{m} \mathrm{m}^{-2} \mathrm{~d}^{-1}$ for $\mathrm{N}$ and $6.4(\mathrm{SE}=1.5) \mathrm{mmol} \mathrm{m}^{-2} \mathrm{~d}^{-1}$ for $\mathrm{C}$ (Figure 5). These rates most likely reflect sinking and grazing losses. This overall decrease in phytoplankton biomass indicated the end of a regional diatom bloom that had peaked several weeks prior to our arrival, and is supported by deep trap fluxes of biogenic silica and POC (Honda, unpublished data).

\subsection{Carbon and nitrogen based production}

We determined that the $\mathrm{N}_{2}$ fixation rates were insignificant and thus the principal sources of inorganic nitrogen for phytoplankton nutrition are ammonium and nitrate (Table 1; Figure 6). In the vicinity of the DCM, while nitrate uptake rates became negligible because of light limitation, ammonium uptake did continue to be significant. Since heterotrophic bacteria can account for a large fraction of total ammonium assimilation (Kirchman, 1994), we estimated this contribution using Eq. (3). The percentage attributable to bacteria amounted to $14-17 \%$, which roughly corresponds to the lower quartile range of the values reported by Kirchman (1994) for marine systems. It reflects an averaged bacterial to primary production ratio of $\sim 11 \%$ (Table 2 ). This is consistent with other synthesized data in the subarctic Pacific, where bacterial production was found to represent $5-15 \%$ of the local primary production (Kirchman et al., 1993). It was also 
suggested that bacterial ammonium uptake in the subarctic Pacific could be limited by the supply of organic carbon (Kirchman et al., 1990). Euphotic zone depth-integrated nitrogen production decreased from $0.53(\mathrm{SE}=0.02)$ during $\mathrm{D} 1$ to $0.44(\mathrm{SE}=0.04)$ mmol $\mathrm{m}^{-2} \mathrm{~h}^{-1}$ during D2. While ammonium uptake did not change significantly, fluctuating randomly around $0.39(\mathrm{SE}=0.02) \mathrm{mmol} \mathrm{m}^{-2} \mathrm{~h}^{-1}$, nitrate uptake decreased regularly from 0.15 to $0.09 \mathrm{mmol} \mathrm{m}^{-2} \mathrm{~h}^{-1}$ during $\mathrm{D} 1$ to reach a background level of 0.07 $(S E=0.01) \mathrm{mmol} \mathrm{m}^{-2} \mathrm{~h}^{-1}$ in $\mathrm{D} 2$, as the diatom bloom ended (Figure 7). It follows that the $f$ ratio (the ratio of $\mathrm{NO}_{3}$ based production divided by the total inorganic $\mathrm{N}$ production), decreased from $28 \%$ to $19 \%$ during D1 reaching an average value of $17 \%$ during D2. It is likely that these $f$ values are to be maximum estimates since regenerated production on other nitrogenous substrates such as amino acids and urea were not considered in this study. It is less clear how the uptake of ammonium by heterotrophic bacteria may affect the $f$ ratio, but competition for ammonium could select for small cells and may force large phytoplankton to use nitrate (Kirchman et al., 1990). Specific nitrate uptake rates ranged between 0.010 to $0.026 \mathrm{~d}^{-1}$, which are typical values reported in HNLC waters (Dugdale and Wilkerson, 1992). It should be noted, however, that these rates are not enough to overcome biomass losses by sinking and predation.

Net primary production (NPP) was measured either by ${ }^{13} \mathrm{C}$ or ${ }^{14} \mathrm{C}$ techniques (Boyd et al., this issue), both providing essentially comparable results (paired $t$ test, $p=0.324$; see Figure 8). New production rates ("exportable production") were then calculated as the product $f$ ratio $\mathrm{x}$ NPP. During the trap deployments, K2 was characterized by a sudden decrease in primary production (523 to $404 \mathrm{mg} \mathrm{C} \mathrm{m}^{-2} \mathrm{~d}^{-1}$ on an average basis) and a downward trend in new production (164 to $67 \mathrm{mg} \mathrm{C} \mathrm{m}^{-2} \mathrm{~d}^{-1}$ ). Synthesized data for the western subarctic Pacific (Imai et al., 2002; Wong et al., 2002; Kawakami and Honda, 2007 ) indicated that primary productivity had a distinct seasonal variation with a 10 -fold range during winter-spring ( $50-550 \mathrm{mg} \mathrm{C} \mathrm{m}^{-2} \mathrm{~d}^{-1}$ ) and that the yearly averaged new production as estimated from the seasonal drawdown of nitrate ranged from 125 to 230 $\mathrm{mg} \mathrm{C} \mathrm{m} \mathrm{m}^{-2}$. These results suggest that we just missed the productivity peak for both NPP and NP in July 2005. Figure 9 shows the relationships between the measured carbon 
and inorganic nitrogen assimilation rates in the euphotic zone. Spearman 's rank order correlation coefficient was $0.86(p<0.001)$ suggesting that $74 \%$ of the variation in either variable is explained by its correlation with the other. The slope of the fitted line (regression coefficient $\pm \mathrm{SE}$ ) is:

$$
U C=(7.6 \pm 1.0) \cdot U D I N
$$

Photosynthesis was, however, better correlated with ammonium assimilation (Spearman $\mathrm{R}=0.794, \mathrm{p}<0.001$ ) than with nitrate (Spearman $\mathrm{R}=0.716, \mathrm{p}<0.001$ ). Multiple regression analysis indicated, moreover, that slopes of the photosynthetic rate versus either ammonium or nitrate assimilation rates were different:

$$
U C=(6.5 \pm 1.9) \cdot U N H_{4}+(9.8 \pm 3.4) \cdot U N O_{3}
$$

Possible explanations for the slope difference are as follows:

(i) Small size phytoplankton cells used ammonium preferentially over nitrate in a regenerated production loop (Harrison and Wood, 1988) and with C/N uptake ratio close to Redfield. For instance, size fractionated ${ }^{14} \mathrm{C}$ uptake experiments indicated that $0.2-2 \mu \mathrm{m}$ phytoplankton cells represented from 50 to $59 \%$ of the total production during trap deployments (Boyd et al., this issue) and $\sim 60 \%$ of the variation in either $\mathrm{UC}$ and $\mathrm{UNH}_{4}$ are explained by their correlation. At $\mathrm{K} 2$, the picoplankton community was dominated by Synechococccus, picoeukaryotes and heterotrophic bacteria (Zhang et al., this issue).

(ii) The decline in the bloom of large diatoms exhibited progressive uncoupling between $\mathrm{C} / \mathrm{N}$ uptake ratios while running mainly on new production and its nitrate source. It was shown that the $>20 \mu \mathrm{m}$ contribution to primary production decreased from 30 to $19 \%$ between D1 and D2, respectively (Boyd et al., this issue) in parallel with the decreasing $f$ ratio ( 28 to $17 \%$ ). During this period, a decrease of fucoxanthin concentration from 100 to $40 \mathrm{ng} \mathrm{L^{-1 }}$ was also noted; the loss of diatoms corresponding to a relatively greater abundance of other chromatophytes with a small unchanging fraction of cyanobacteria (Buesseler et al. this issue). It was 
suggested that the end of the diatom bloom was caused by light and/or iron limitation. Silic acid concentrations remained high, greater than $8 \mu \mathrm{M}$ in the upper ML increasing up to $55 \mu \mathrm{M}$ near $100 \mathrm{~m}$. Moreover values of the photosynthetic competence (Fv/Fm) are consistent with an algal iron stress (Boyd et al., 2008-this issue). If so competition for ammonium induced by heterotrophic bacteria may affect the phytoplankton community structure because the iron demand of phytoplankton cells is higher when growing on nitrate compared to ammonium as $\mathrm{N}$ source (Maldonado and Price, 1996). This implies that in low Fe waters ammonium uptake is preferred and new production progressively suppressed despite the surplus of nitrate.

\subsection{Nitrogen regeneration}

The regeneration of ammonium and nitrate was assessed using results of the ${ }^{15} \mathrm{~N}$ tracer experiments and compartmental modelling (section 2.7). The slight variations of nitrate concentration during the incubation did not allow the nitrification rate to be quantified (Table 1). The ammonium production was compared to nitrogen mineralization as estimated from bacterial production measurements (Table 2). Although these experiments were not performed each time on the same cast, they compared fairly with averaged bacterial remineralisation less than ammonium regeneration (Figure 10). These differences are largely due to the fact that ammonium production involves both ammonification (the bacterial conversion of organic nitrogen back to ammonium) and direct zooplankton excretion or release. Accordingly, we estimated the bacterial contribution to ammonium production to be around $47-94 \%$. The vertical profiles of ammonium assimilation (phytoplankton and bacterial uptake) and production (zooplankton and bacterial release) are shown in Figure 11 with depth-integrated values on the order of 0.39 and $0.57 \mathrm{mmol} \mathrm{m}^{-2} \mathrm{~h}^{-1}$, respectively. This provides a net ammonium production rate of $0.18 \mathrm{mmol} \mathrm{m}^{-2} \mathrm{~h}^{-1}$, which matches the trend for the build-up of ammonium stock observed in Figure 4, i.e. $0.13(\mathrm{SE}=0.02) \mathrm{mmol} \mathrm{m}^{-2} \mathrm{~h}^{-1}$.

\subsection{Carbon budget in the upper $150 m$ at $K 2$}


Since estimates of primary and new production have been made in the euphotic zone, and sinking flux of particulate organic carbon were collected at $150 \mathrm{~m}$, it is possible to assess the balance between autotrophic and heterotrophic processes during our sampling period. During the trap deployment, K2 was characterized both by changes in primary, new and export production (Table 2). The data indicate that 17 to $23 \%$ of primary production is exportable to deeper layers ( $f$ ratio), but only 6 to $13 \%$ collected as a sinking particle flux at 150m (e ratio; Buesseler et al., 2007a). Hence, 77 to $85 \%$ of the carbon fixed by phytoplankton would be mineralized in the upper 50m ( 1 - $f$ ratio), while $<11 \%$ would be within 50 and $150 \mathrm{~m}$ ( $f-e$ ratios). Yet this information should carefully be considered since neither $f$ and $e$ ratios represent a fractional POC export assessed on a seasonal or steady state basis. The annual $f(42 \%)$ and $e$ ratios $(29 \%)$ in the western subarctic gyre (Kawakami and Honda, 2007) were greater than those reported in this study. This is not too surprising since with an assemblage dominated by picoplankton (50-59\%) there will be little sinking of biogenic material unless the cells aggregate, and we just passed over the new production peak. In contrast herewith, the difference in the percentage of the export ratio $e$ is likely due to methodological issues. Kawakami and Honda (2007) estimated the POC flux from the surface layer using ${ }^{234} \mathrm{Th}$ as a tracer. At $\mathrm{K} 2$, these fluxes varied seasonally from 57 to $179 \mathrm{mg} \mathrm{C} \mathrm{m}^{-2} \mathrm{~d}^{-1}$ and were much higher during summer than those measured here with NBSTs (Table 2). Using surface altimetry and ADCP data, likely particle source funnels for the $150 \mathrm{~m}$ NBST were up to $40 \mathrm{~km}$ west and $20-40 \mathrm{~km}$ north during D1 or $20-40 \mathrm{~km}$ south during D2 (Buesseler et al., 2008-this issue). Further comparisons among the VERTIGO traps, and between the VERTIGO results are discussed in companion papers (Buesseler et al., Lamborg et al. and Trull et al. 2008-this issue). With a POC loss rate of $77 \mathrm{mg} \mathrm{C} \mathrm{m}^{-2} \mathrm{~d}^{-1}$ in the upper $50 \mathrm{~m}$ (see Figure 5), one can estimate the quantity of carbon available to meet the metabolic requirements of the heterotrophic community (HCD) with:

$$
\frac{d P O C}{d t}=N P P-H C D-N P
$$


where NPP stands for net primary production and NP for new production, assumed to represent the exportable carbon flux out of the euphotic zone. Within this context, it should be stressed that our NP estimates (D1: $119 \pm 42$ and D2: $67 \pm 23 \mathrm{mg} \mathrm{C} \mathrm{m}^{-2} \mathrm{~d}^{-1}$ ) are consistent with predicted POC export values of $66-166$ (D1) and $23-43$ (D2) mg C $\mathrm{m}^{-2} \mathrm{~d}^{-1}$ computed with a planktonic foodweb model (Boyd et al., 2008-this issue). In this model, two scenarios were selected to constrain the upper and lower bounds of the predicted export flux. The lower value corresponds to a faecally mediated flux where all NPP is transformed by a micro- and meso-zooplankton (copepod) dominated foodweb into faecal material, which exits the base of the euphotic zone. The upper value corresponds to an algal/faecal mediated flux in which all of NPP by $>20 \mu \mathrm{m}$ cells exits the euphotic zone as intact cells, but all of the NPP by cells $<20 \mu \mathrm{m}$ is transformed by the pelagic foodweb.

Table 2 indicates that in the trophogenic zone, HCD is roughly equivalent to the primary production rate, and represents between 43 to $67 \%$ of the incoming new production flux in the subsurface layer $(50-150 \mathrm{~m})$. In the top $50 \mathrm{~m}$, the median of the bacterioplankton carbon demand (the carbon required for respiration and growth) was estimated to be about $340 \mathrm{mg} \mathrm{C} \mathrm{m} \mathrm{m}^{-2}$, which is equivalent to $>70 \%$ of the primary production. If we assume that bacteria and zooplankton graze only on phytoplankton, then the bacterial demand for carbon far outweighed the zooplankton demand for carbon fixed by photosynthesis within the euphotic zone. This is, however, a questionable assumption since the dissolved and particulate organic carbon utilized by bacteria is generated by a number of different processes including copepods grazing on microzooplankton and microzooplankton grazing on bacteria themselves. It follows that this assumption will probably maximize the demand of bacteria for phytoplankton production, and hence minimize the quantity available for microzooplankton and mesozooplankton grazing (carbon assimilated for use in respiration, growth, excretion, and reproduction). It should be noted that the feeding rate of the copepod community on the mixed layer phytoplankton was estimated around 60 to $105 \mathrm{mg} \mathrm{C} \mathrm{m}^{-2} \mathrm{~d}^{-1}$, representing $<20 \%$ of the primary production (Kobari et al., 2008-this issue). This suggests that microzooplankton 
could be both the main herbivores, and an important prey source for copepods in the euphotic zone (Boyd et al., this issue). Between 50 and $150 \mathrm{~m}$ the carbon requirement of bacteria decreased down to $60 \mathrm{mg} \mathrm{C} \mathrm{m}^{-2} \mathrm{~d}^{-1}$, which is equivalent to the carbon available for the whole heterotrophic demand (Table 2). Dissolved organic carbon (DOC) is another important source that has not been addressed directly in the present analysis although it is involved in the HCD estimates, e.g. release of DOC during grazing. Moreover, not all of the exportable carbon estimated from new production is exported as a vertical POC flux; part may be exported out of the area by advective transport of either POC or DOC (Bronk et al., 1994). In the mesopelagic (below $150 \mathrm{~m}$ ) the vertical supply of DOC from the euphotic zone could support a portion of the heterotrophic carbon demand, but not sufficiently (Steinberg et al., 2008). Instead, the mesopelagic carbon demand is probably sustained by the surface feeding of migrating zooplankton and their transport back to deeper layers, where they can excrete dissolved organic matter and release faecal pellets (Steinberg et al., 2008). This observation must be taken into account for the interpretation of data in Table 2 since it would bypass the shallow traps.

\subsection{Nitrogen budget in the upper $150 \mathrm{~m}$ at $\mathrm{K} 2$}

From the measured $150 \mathrm{~m}$ PN flux to the inorganic nitrogen production ratio, it can be stated that $\sim 95$ to $98 \%$ of nitrogen would be mineralized in the upper $150 \mathrm{~m}$ during D1 and D2, respectively (Table 3). Figure 11 suggests that most of the shallow nitrogen mineralization occurred just above the DCM (20 - $40 \mathrm{~m})$ where a net ammonium production was found. Nitrification rates being below detection, it is assumed that the nitrate utilization by phytoplankton was balanced by the supply of nitrate from below the euphotic zone (Table 3). As for $C$, the nitrogen metabolic requirement of the heterotrophic community (HND) was assessed with the following mass balance differential equation:

$$
\frac{d P N}{d t}=U D I N-H N D-U N O_{3}
$$


where UDIN stands for dissolved inorganic nitrogen based production and $\mathrm{UNO}_{3}$ for the nitrate uptake, i.e., assumed to be equivalent to the exportable $\mathrm{N}$ flux.

The results are very similar to those obtained for carbon in the upper $50 \mathrm{~m}$, i.e., HND is roughly equivalent to the autotrophic nitrogen based production (Table 3 ). In the subsurface layer (50-150m), HND represents more than $80 \%$ of the incoming vertical nitrogen flux, which possibly reflect the regeneration and use of nitrogenous labile compounds (ammonium and nitrite) immediately below the DCM as suggested in Figure 3. Also, these results for extensive shallow $\mathrm{N}$ regeneration are supported by estimates of shallow PN remineralisation determined by Buesseler et al. (2008-this issue) by comparing the longer-term seasonal changes in upper ocean $\mathrm{N}$ stocks to the $150 \mathrm{~m}$ PN flux.

\section{Conclusions and summary}

During summer 2005, it is clearly apparent that C and $\mathrm{N}$ uptake in the euphotic zone were not sufficiently rapid to overcome grazing pressure and sinking losses. Biomass did not build-up, because of the small size of the phytoplankton population $(0.2-2 \mu \mathrm{m})$, which represented 50 to $59 \%$ of the total production (Boyd et al., 2008-this issue), and which likely chose ammonium over nitrate as nitrogen substrate. High rates of new production were not attained as a result of both low specific nitrate uptake $(0.025$ to $0.010 \mathrm{~d}^{-1}$ ) and low biomass ( $<60$ and $350 \mathrm{mmol} \mathrm{m}^{-2}$ for PN and POC in the upper $50 \mathrm{~m}$ ). According to our estimates, the available carbon and nitrogen for herbivores were roughly equivalent to primary production. Recycling within the water column is the dominant process, and $\mathrm{C}-\mathrm{N}$ assimilated by phytoplankton were rapidly regenerated and consumed by heterotrophs within or just below the euphotic zone (Table $2 \& 3$ ). As determined from SeaWIFS images (Honda and Watanabe, 2007), we just captured the end of a diatom bloom. The decrease in $f$ ratio ( 28 to $17 \%$ ) and new production followed the collapse of the bloom. The contribution of large diatom cells $>20 \mu \mathrm{m}$ to total production decreased from 30 to $19 \%$ between trap deployments (Boyd et al., 2008-this issue). Competition for ammonium, which can be induced by heterotrophic bacteria, 
could select for small cells and may force large diatoms to use nitrate. This implies that under Fe stress as observed here, ammonium uptake was preferred and new production progressively suppressed despite the surplus of nitrate. More controversy has arisen over the interpretation that new production represent an export flux of particles out of the euphotic zone (Eppley, 1989, Platt et al., 1992; Bronk et al., 1994; Yool et al., 2007) and NP could be better considered as "exportable" rather than an export flux, although in reality it is a related concept that probably represent an overestimate. At $K 2$, the ratio $e / f$, equivalent to the ratio of export $(0-150 m)$ to new production $(0-50 m)$ ranged from 0.34 to 0.57 within the range of most previous estimates in the North Pacific Ocean (Kawakami and Honda, 20007 and references therein). It suggests that 52 to $44 \mathrm{mg} \mathrm{C}$ $\mathrm{m}^{-2} \mathrm{~d}^{-1}$ of new production should be grazed and / or released as DOC between 50 and $150 \mathrm{~m}$. These values are not unfounded regarding the metabolic carbon demand estimated for euphotic (Kobari et al., 2008-this issue) and mesopelagic (Steinberg et al., 2008) biota.

\section{Acknowledgements}

We acknowledge the skilful assistance of captain and crew of R/V Revelle during work at sea. This research was supported by the Research Foundation Flanders through grant G.0021.04 and Vrije Universiteit Brussel via grant GOA 22, as well as the US National Science Foundation programs in Chemical and Biological Oceanography. We also extend our thanks to the anonymous reviewers for their many fruitful comments.

\section{References}

Boyd, P.W., Gall, M.P., Silver, M., Quantifying the surface-subsurface biogeochemical coupling during the VERTIGO HOT and K2 experiments, this issue.

Bronk, D. A., P. M. Glibert, and B. B. Ward (1994), Nitrogen uptake, dissolved organic nitrogen release, and new production, Science, 265, $1843-1846$.

Buesseler, K.O., Antia, A.N., Chen, M., Fowler, S.W., Gardner, W.D., Gustafsson, O., Harada, K., Michaels, A.F., Rutgers van der Loeff, M., Sarin, M., Steinberg, D.K., Trull, 
T. (2007b). An assessment of the use of sediment traps for estimating upper ocean particle fluxes. Marine Chemistry. Accepted in Journal of Marine Research.

Buesseler, K.O., C.R. Benitez-Nelson, S.B. Moran, A. Burd, M. Charette, J. K. Cochran, L. Coppola, N.S. Fisher, S.W. Fowler, W.D. Gardner, L.D. Guo, O. Gustafsson, C. Lamborg, P. Masque, J.C. Miquel, U. Passow, P.H. Santschi, N. Savoye, G. Stewart and T. Trull (2006). An assessment of particulate organic carbon to thorium-234 ratios in the ocean and their impact on the application of ${ }^{234} \mathrm{Th}$ as a POC flux proxy. Marine Chemistry, 100: 213-233.

Buesseler, K.O., et al., An overview of Twilight Zone processes in the N. central Pacific and NW Pacific, this issue.

Buesseler, K.O., Lamborg, C.H., Boyd, P.W., Lam, P.J., Trull, T.W., Bidigare, R.R., Bishop, J.K.B., Casciotti, K.L., Dehairs, F., Elskens, M., Honda, M., Karl, D.M., Siegel, D., Silver, M.W., Steinberg, D.K., Valdes, J., Van Mooy, B., Wilson, S., (2007a). Revisiting carbon flux through the ocean's twilight zone. Science, 316, 567-570.

Currie, L.A. (1995). Nomenclature in evaluation of analytical methods including detection and quantification capabilities (IUPAC recommendations 1995). Pure and Applied Chemistry 67, 1699-1723.

D'Elia, C. (1983), Nitrogen determination in seawater, in Nitrogen in the Marine Environment, edited by E. J. Carpenter and D. G. Capone, pp. 731 - 762, Elsevier, New York.

de Brauwere A., De Ridder F., Elskens M., Schoukens J., Pintelon R., Baeyens W. (2005a). Refined parameter and uncertainty estimation when both variables are subject to error. Case study: Estimation of Si consumption and regeneration rates in a marine environment. Journal of Marine Systems 55: 205-221.

de Brauwere A., De Ridder F., Pintelon R., Elskens M., Schoukens J. and Baeyens W. (2005b). Model selection through a statistical analysis of the minimum of a Weighted 
Least Squares cost function. Chemometrics and Intelligent Laboratory Systems 76: $163-173$.

del Giorgio, P.A., Cole, J.J., (2000). Bacterial energetics and growth efficiency. In: D.L. Kirchman (ed.), Microbial Ecology of the Oceans. Wiley \& Sons, pp 289-325.

Ducklow, H., (2000). Bacterial production and biomass in the oceans. In: D.L. Kirchman (ed.), Microbial Ecology of the Oceans. Wiley \& Sons, pp 85-152.

Dugdale, R. C., and J. J. Goering (1967), Uptake of new and regenerated forms of nitrogen in primary productivity, Limnol. Oceanogr., 12, $196-206$.

Dugdale, R.C. and Wilkerson, F., (1992). Nutrient limitation of new production in the sea. In Primary Productivity and Biogeochemical Cycles in the Sea, edited by P.G. Falkowski and A.D. Woodhead, Plenum Press, New York and London, pp 107-122.

Elskens M., Penninckx M., Vandeloise R. \& Vander Donckt E. (1988), Use of Simplex Technique and contour diagrams for the determination of the reaction rate constants between glutathione and thiram in the presence of NADPH. International Journal of Chemical Kinetics, 20, 837-848.

Elskens, M., Baeyens, W., Cattaldo, T., Griffith, B. and Dehairs, F. (2002). N-uptake conditions during the summer in the sub-Antarctic and Polar Frontal Zones of the Australian sector of the Southern Ocean. Journal of Geophysical Research, 107: 3-13-11.

Elskens, M., Baeyens W., Brion, N, De Galan S, Goeyens L. and de Brauwere, A. (2005). Reliability of $\mathrm{N}$ flux rates estimated from ${ }^{15} \mathrm{~N}$ enrichment and dilution experiments in aquatic systems. Global Biogeochemical Cycles 19, GB4028, doi:10.1029/2004GB002332.

Elskens, M., de Brauwere, A., Beucher, C., Corvaisier, R., Savoye, N., Tréguer, P. and Baeyens, W. (2007). Statistical process control in assessing production and dissolution rates of biogenic silica in marine environments. Marine Chemistry, doi:10.1016/ j.marchem.2007.01.008. 
Emerson, S., P. Quay, D. Karl, C. Winn, L. Tupas, and M. Landry. (1997). Experimental determination of the organic carbon flux from open-ocean surface waters. Nature 389: 427.

Eppley, R. W., and B. J. Peterson (1979). Particulate organic matter flux and planktonic new production in the deep ocean, Nature 282: $677-680$.

Eppley, R.W. (1989). New production: History, methods, problems. In Productivity of the Ocean: Present and Past, edited by W.H. berger, V.S. Smetacek and G. Wefer, pp. 8597, John Wiley \& Sons Limited. S. Bernhard, Dahlem Konferenzen.

Falkowski, P.G; (1997). Evolution of the nitrogen cycle and its influence on the biological sequestration of $\mathrm{CO} 2$ in the ocean. Nature 387: 272-275.

Fuhrman, J.A., Azam. F. (1982). Thymidine incorporation as a measure of heterotrophic bacterioplankton production in marine surface waters: Evaluation and field results. Marine Biology 66: 109-120.

Glibert, P. M., and D. G. Capone (1993), Mineralization and assimilation in aquatic, sediment and wetland systems, in Nitrogen Isotope Techniques, edited by R. Knowles and T. H. Blackburn, pp. 243 - 272, Elsevier, New York.

Hansen, H. P., and K. Grasshoff (1983). Automated chemical analysis, in Methods of Sea water Analysis, edited by K. Grasshoff , M. Ehrhardt, and K. Kremling, 2nd ed., pp. 368 - 376, Verlag Chemie, Weinheim, Germany.

Harrison, W.G. (1983). Use of isotopes, in Nitrogen in the Marine Environment, edited by E.J. Carpenter and D. G. Capone, pp. 763 - 807, Academic Press, New York, London.

Harrison, W.G., Wood, L.J. (1988). Inorganic nitrogen uptake by marine picoplankton: evidence for size partitioning. Limnology and Oceanograpgy 33: 468-475.

Honda M.C. and S. Watanabe (2007). Utility of an automatic water sampler to observe seasonal variability in nutrients and DIC in the NW North Pacific. Journal of Oceanography 63: 349-362. 
Honda, M.C., 2003. Biological pump in the northwestern North Pacific. Journal of Oceanography 59: 671-684.

Honda, M.C., Kawakami, H., Sasaoka, K., Watanabe, S., Dickey, T., (2006). Quick transport of primary produced organic carbon to the ocean interior. Geophysical Research Letters 33 doi:101029/2006GL026466.

Imaii, K., Nojiri, Y., Tsurushima, N., Saino, T. (2002). Time-series of seasonal variation of primary productivity at station KNOT $\left(44^{\circ} \mathrm{N}, 155^{\circ} \mathrm{E}\right)$ in the sub-arctic western North Pacific. Deep-Sea Research II 49: 5395-5408.

Kawakami, H., Honda, M.C. (2007). Time-series observation of POC fluxes estimated from $234^{\text {Th }}$ in the northwestern North Pacific. Deep-Sea Research I 54: 1070-1090.

Kirchman, D.L., Keil, R.G., Wheeler, P.A. (1990). Carbon limitation of ammonium uptake by heterotrophic bacteria in the subarctic Pacific. Limnology and Oceanography 35: $1258-1266$.

Kirchman, D.L., Keil, R.G., Simon M., Welscmeyer, N.A. (1993). Biomass and production of heterotrophic bacterioplankton in the oceanic subarctic Pacific. Deep-Sea Research 40: $967-988$.

Kirchman, D.L. (1994); The uptake of inorganic nutrients by heterotrophic bacteria. Microbial Ecology 28: 255-271

Kobari, T., D.K. Steinberg, A. Ueda, A. Tsuda, M.W. Silver and M. Kitamura (2008). Impacts of ontogenetically migrating copepods on downward carbon flux in the western subarctic Pacific Ocean. Deep Sea Research II, this volume.

Koroleff, F., Determination of ammonia, in Methods of Seawater Analysis, edited by K. Grasshoff, pp. 126 - 133, Verlag Chemie, Weinheim, Germany, 1976.

Lamborg, C.H., Buesseler, K.O., Valdes J., Bertrand, C.H., Manganini S., Pike S., Steinberg D., Trull T., Wilson S., The flux of major, minor and trace elements associated with sinking particles in the mesopelagic "Twilight Zone" of the Northwest and North Central Pacific Ocean, this issue. 
Legendre, L. and Gosselin, M. (1996). Estimation of N or C uptake rates by phytoplankton using $15 \mathrm{~N}$ or $13 \mathrm{C}$ : revisiting the usual computation formulae, J. Plank. Res., 19, 263- 271.

Longhurst, A.R., Harrison, W.G. (1989). The biological pump - Profiles of plankton production and consumption in the upper ocean. Progress in Oceanography, 22, 47123.

Maldonato, M.T., Price, N.M. (1996). Influence of $\mathrm{N}$ substrate on Fe requirements of marine centric diatoms. Marine Ecology Progress Series 141: 161-172.

Mandel, J. (1964). The statistical analysis of experimental data. Wiley, New York.

Nieuwenhuize, J., Y. E. M. Maas, and J. Middelburg (1994), Rapid analysis of organic carbon and nitrogen in particulate materials, Mar. Chem., 45, $217-224$.

Orcutt, K.M., Lipschultz, F., Gundersen, K., Arimoto, R., Michaels, A.F., Knap, AH., Gallon, J.R. (2001). A seasonal study of the significance of N-2 fixation by Trichodesmium spp. at the Bermuda Atlantic Time-series Study (BATS) site. Deep-Sea Research Part II, 48, 1583-1608.

Pace, M.L., G.A. Knauer, D.M. Karl, and J.H. Martin, (1987). Primary production, new production and vertical flux in the Eastern Pacific, Nature, 325, 803-804.

Platt, T., Jauhari, P., Sathyendranath, S. (1992). The importance of measurement of new production. In Primary Productivity and Biogeochemical Cycles in the Sea, edited by P.G. Falkowski and A.D. Woodhead, Plenum Press, New York and London, pp 275-284.

Reuer, M.K., Barnett, B.A., Bender, M.L., Falkowski, P.G., Hendricks, M.B. (2007). New estimates of Southern Ocean biological production rates from $\mathrm{O}_{2} / \mathrm{Ar}$ ratios and the triple isotope composition of $\mathrm{O}_{2}$; Deep-Sea Research Part I, 54, 951-974.

Sambrotto, R.N., Mace, B.J., 2000. Coupling of biological and physical regimes across the Antarctic Polar Front as reflected by nitrogen production and recycling. Deep-Sea Research II 47 (15-16), 3339-3367. 
Suter G.W. (2007). Variability, uncertainty and probability. In Ecological Risk Assessment, pp. 69-94. CRC Press, Boca Raton, London, New York.

Steinberg, D.K., Van Mooy, B.A.S., Buesseler, K.O., Boyd, P.W., Kobari T., Karl, D.M., Microbial vs. zooplankton control of sinking particle flux in the ocean's twilight zone. Limnology and Oceanography. In press.

Trull T. W., Bray S., Buesseler K. O., Lamborg C. H., Manganini S., Moy C., and Valdes J. , 2008. In-situ measurement of mesopelagic particle sinking rates and the control of carbon transfer to the ocean interio during the Vertical Flux in the Global Ocean (VERTIGO) voyages in the North Pacific. Deep Sea Research II, this volume.

Wong, C.S., Waser, N.A.D., Nojiri, Y., Whitney, F.A., Page, J.S., Zeng, J. (2002). Seasonal cycles of nutrients and dissolved inorganic carbon at high and mid latitudes in the North Pacific Ocean during the Skaugran cruises: determination of new production and nutrient uptake ratios. Deep-Sea Reearch II 49: 5317-5338.

Yool, A., Martin, A.P., Fernandez, C., Clark, D.R. (2007). The significance of nitrification for oceanic new production. Nature, 447, doi:10.1038/nature05885, 999-1002.

Zhang, Y., Jiao, N.Z., Hong, N., 2008. Comparative studies on picoplankton biomass and community structure in different provinces from subarctic to subtropical oceans. Deep Sea Research II, this volume. 


\section{Tables}

Table 1: Uncertainty / Variability dichotomy in assessing uptake (U) and regeneration (R) rates of dissolved inorganic carbon and nitrogen. Uncertainty represents the random error propagations through rate calculations, while variability covers changing environmental conditions and sampling. Accuracy refers to the probability of the residual cost function value. It is acceptable when $<\chi^{2} 95 \%$ (section 2.8). MDL stands for method or model detection limit.

\begin{tabular}{lccccc}
\hline Substrate & $\begin{array}{c}\text { Tracer } \\
\text { addition } \%\end{array}$ & Rate & $\begin{array}{c}\text { Relative } \\
\text { Uncertainty \% }\end{array}$ & $\begin{array}{c}\text { Relative } \\
\text { Variability \% }\end{array}$ & Accuracy \\
\hline${ }^{15} \mathrm{NH}_{4} \mathrm{Cl}$ & $2-14$ & $\mathrm{UNH}_{4}$ & 7.7 & 14.4 & $<\chi^{2} 95 \%$ \\
& $1-2$ & $\mathrm{RNH}_{4}$ & 22.7 & 22.4 & $<\chi^{2} 95 \%$ \\
$\mathrm{~K}^{15} \mathrm{NO}_{3}$ & $7-10$ & $\mathrm{UNO}_{3}$ & 17.7 & 34.6 & $<\chi^{2} 95 \%$ \\
${ }^{15} \mathrm{RN}_{2}$ & $\mathrm{UN}_{2}$ & - & - & $<\mathrm{MDL}$ \\
$\mathrm{Na}_{2}{ }^{13} \mathrm{CO}_{3}$ & $8-11$ & $\mathrm{UC}$ & 5 & - & $<\mathrm{MDL}$ \\
\hline
\end{tabular}

Table 2: Carbon budget at K2. Carbon flux rates were assessed as described in the text. Values are mean \pm standard error. The standard error of the mean reflects the sampling variability.

\begin{tabular}{|c|c|c|c|c|}
\hline Depth & Symbol & $\begin{array}{l}\text { Carbon flux rate } \\
\left(\mathrm{mg} \mathrm{C} \mathrm{m} \mathrm{m}^{-2} \mathrm{~d}^{-1}\right)\end{array}$ & $\begin{array}{c}\text { D1 } \\
31 / 07- \\
06 / 08 / 05\end{array}$ & $\begin{array}{c}\text { D2 } \\
11 / 08- \\
16 / 08 / 05\end{array}$ \\
\hline \multirow{7}{*}{$0-50 m$} & NPP & Net primary production & $523 \pm 58$ & $403 \pm 14$ \\
\hline & & Bacterial production & $51 \pm 2$ & $49 \pm 8$ \\
\hline & $\mathrm{RP}=(1-f) . \mathrm{NPP}$ & Regenerated production & $404 \pm 42$ & $336 \pm 17$ \\
\hline & $\mathrm{NP}=f . \mathrm{NPP}$ & New production & $119 \pm 21$ & $67 \pm 12$ \\
\hline & $\mathrm{dPOC} / \mathrm{dt}$ & Rate of POC change (Fig. 5b) & \multicolumn{2}{|c|}{$-77 \pm 12$} \\
\hline & $\mathrm{HCD}$ & $\begin{array}{l}\text { Available } C \text { for heterotrophic } \\
\text { community (Eq. } 8 \text { ) }\end{array}$ & $481 \pm 62$ & $414 \pm 19$ \\
\hline & $\begin{array}{l}\mathrm{BCD} \\
1-f\end{array}$ & $\begin{array}{l}\text { Bacterial carbon demand } \\
\% \text { POC remineralization }\end{array}$ & $\begin{array}{l}343 \pm 13 \\
77 \%\end{array}$ & $\begin{array}{c}328 \pm 51 \\
83 \%\end{array}$ \\
\hline \multirow{5}{*}{$50-150 m$} & & Exportable C flux & $119 \pm 21$ & $67 \pm 12$ \\
\hline & BP & Bacterial production & $9 \pm 3$ & $10 \pm 3$ \\
\hline & $\mathrm{dPOC} / \mathrm{dt}$ & Rate of POC change & \multicolumn{2}{|c|}{$\sim 0$} \\
\hline & $\mathrm{HCD}$ & $\begin{array}{l}\text { Available } C \text { for heterotrophic } \\
\text { community (Eq. } 8 \text { ) }\end{array}$ & $51 \pm 21$ & $45 \pm 12$ \\
\hline & $\begin{array}{l}\mathrm{BCD} \\
f-e \\
\end{array}$ & $\begin{array}{l}\text { Bacterial carbon demand } \\
\% \text { POC remineralization }\end{array}$ & $\begin{array}{c}61 \pm 20 \\
10 \% \\
\end{array}$ & $\begin{array}{c}65 \pm 25 \\
11 \% \\
\end{array}$ \\
\hline \multirow[t]{2}{*}{$150 m$} & $\mathrm{POCF}_{150}$ & $\begin{array}{l}\text { NBST POC flux (Buessseler et al., } \\
2007 a)\end{array}$ & $68 \pm 2$ & $23 \pm 2$ \\
\hline & $1-e$ & $\%$ POC remineralization & $87 \%$ & $94 \%$ \\
\hline
\end{tabular}


Table 3: Nitrogen budget at $\mathrm{K} 2$. Nitrogen flux rates were assessed as described in the text. Values are mean \pm standard error. The standard error of the mean reflects the sampling variability.

\begin{tabular}{|c|c|c|c|c|}
\hline Depth & Symbol & 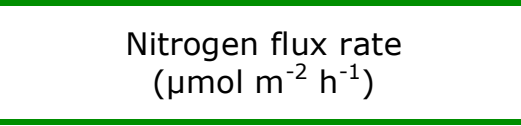 & $\begin{array}{c}D 1 \\
31 / 07- \\
06 / 08 / 05\end{array}$ & $\begin{array}{c}\mathrm{D} 2 \\
11 / 08- \\
16 / 08 / 05\end{array}$ \\
\hline \multirow{7}{*}{$0-50 m$} & UDIN & DIN uptake & $525 \pm 18$ & $443 \pm 35$ \\
\hline & $\mathrm{UNH}_{4}$ & Ammonium uptake & $408 \pm 14$ & $370 \pm 37$ \\
\hline & $\mathrm{UNO}_{3}$ & Nitrate uptake & $118 \pm 14$ & $73 \pm 11$ \\
\hline & $\mathrm{RNH}_{4}$ & \multirow{4}{*}{$\begin{array}{l}\text { Ammonium regeneration } \\
\text { Nitrate regeneration } \\
\text { Rate of PN change (Fig. } 5 \mathrm{a} \text { ) } \\
\text { Available } \mathrm{N} \text { for heterotrophic } \\
\text { community (Eq. } 9 \text { ) } \\
\% \text { PN remineralization }\end{array}$} & \multirow{2}{*}{\multicolumn{2}{|c|}{$\begin{array}{c}570 \pm 80 \\
<\mathrm{MDL} \\
-40 \pm 6\end{array}$}} \\
\hline & $\begin{array}{l}\mathrm{RNO}_{3} \\
\mathrm{dPN} / \mathrm{dt}\end{array}$ & & & \\
\hline & HND & & $447+23$ & $410+37$ \\
\hline & $\mathrm{UNH}_{4} / \mathrm{UDIN}$ & & $78 \%$ & $84 \%$ \\
\hline \multirow{4}{*}{$0-150 m$} & $\mathrm{dPN} / \mathrm{dt}$ & \multirow{4}{*}{$\begin{array}{c}\text { Rate of PN change } \\
\text { Exportable } \mathrm{N} \text { flux } \\
\text { Available } \mathrm{N} \text { for heterotrophic } \\
\text { community (Eq. } 9 \text { ) } \\
\% \mathrm{PN} \text { remineralization }\end{array}$} & \multicolumn{2}{|c|}{$\sim 0$} \\
\hline & $\mathrm{UNO}_{3}$ & & $118 \pm 14$ & $73 \pm 11$ \\
\hline & HND & & $93 \pm 14$ & $64 \pm 11$ \\
\hline & $\begin{array}{c}\left(\mathrm{UNO}_{3}-\mathrm{PNF}_{150}\right) / \\
\text { UDIN }\end{array}$ & & $17 \%$ & $14 \%$ \\
\hline \multirow[t]{2}{*}{$150 \mathrm{~m}$} & $\mathrm{PNF}_{150}$ & $\begin{array}{c}\text { NBST PN flux (Buessseler et al., } \\
2007 a)\end{array}$ & $25 \pm 2$ & $9 \pm 1$ \\
\hline & $1-\mathrm{PN}_{\mathrm{F}} /$ UDIN & \% PN remineralization & $95 \%$ & $98 \%$ \\
\hline
\end{tabular}




\section{Figures}
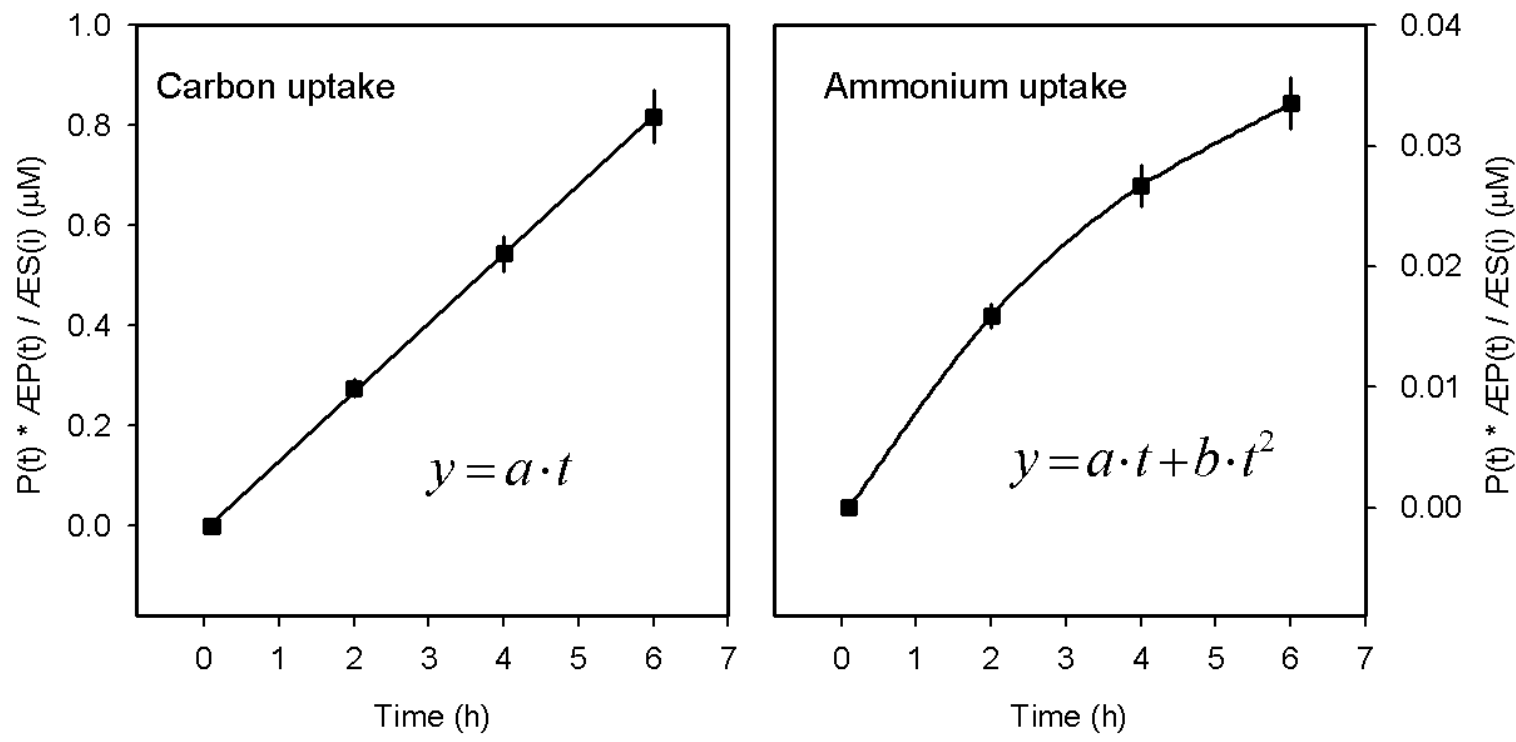

Figure 1: Examples of data, linear vs. curvilinear fits and parameter estimates for carbon and nitrogen uptake rates (Eq. 1). The error bars represent the uncertainty on rate calculations (propagation of random errors, section 2.8). The choice between the linear and quadratic model is made using a Mandel's fitting test (Mandel, 1964). The initial rate $\mathrm{U}$ at $\mathrm{t}=0$ is given by $a$, which provides an estimate of gross uptake rate with unit $\mu \mathrm{M} \mathrm{h} \mathrm{h}^{-1}$.

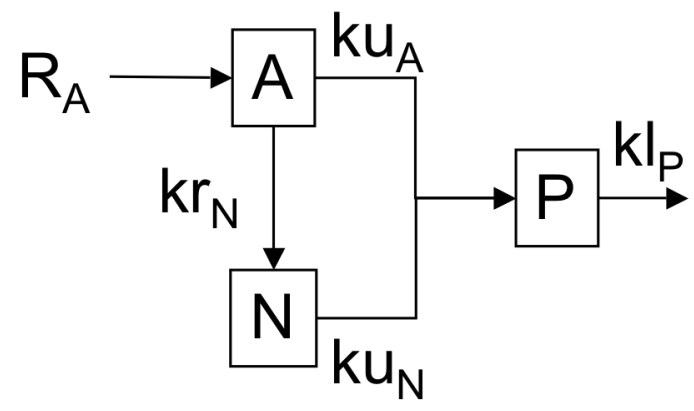

Figure 2: Three compartments open model describing exchange reactions between ammonium $(A)$, nitrate $(N)$ and particulate organic nitrogen $(P) . k$ : rate constants $\left(t^{-1}\right), r$ : regeneration, I: loss, $\mathrm{u}$ : uptake, $\mathrm{R}_{\mathrm{A}}$ : ammonium regeneration rate $\left(\mu \mathrm{M} \mathrm{t}^{-1}\right)$. 


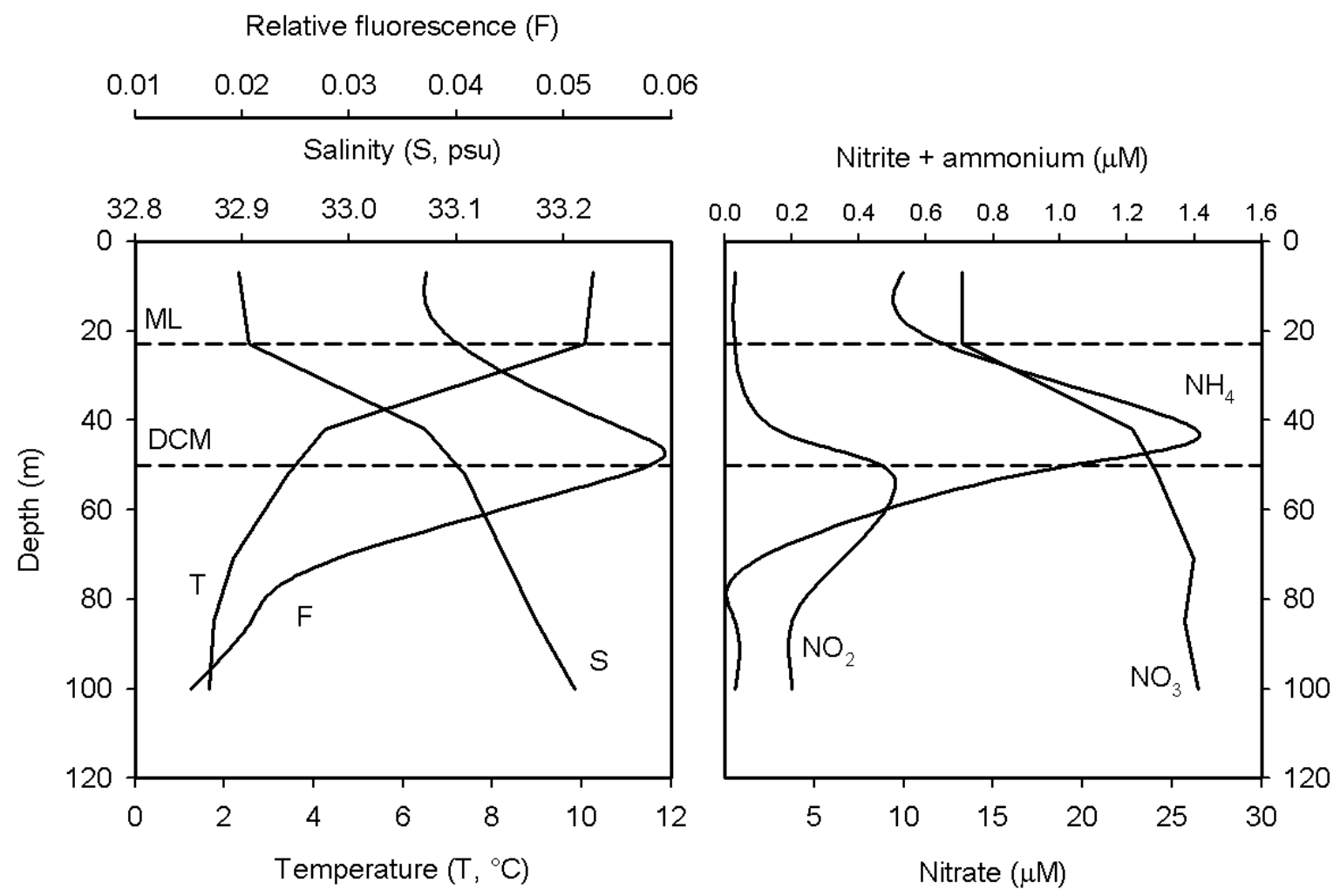

Figure 3: Typical vertical profiles of temperature, salinity, fluorescence and DIN concentrations at K2. Full CTD and bottle data are available on line at http://ocb.whoi.edu/vertigo.html.

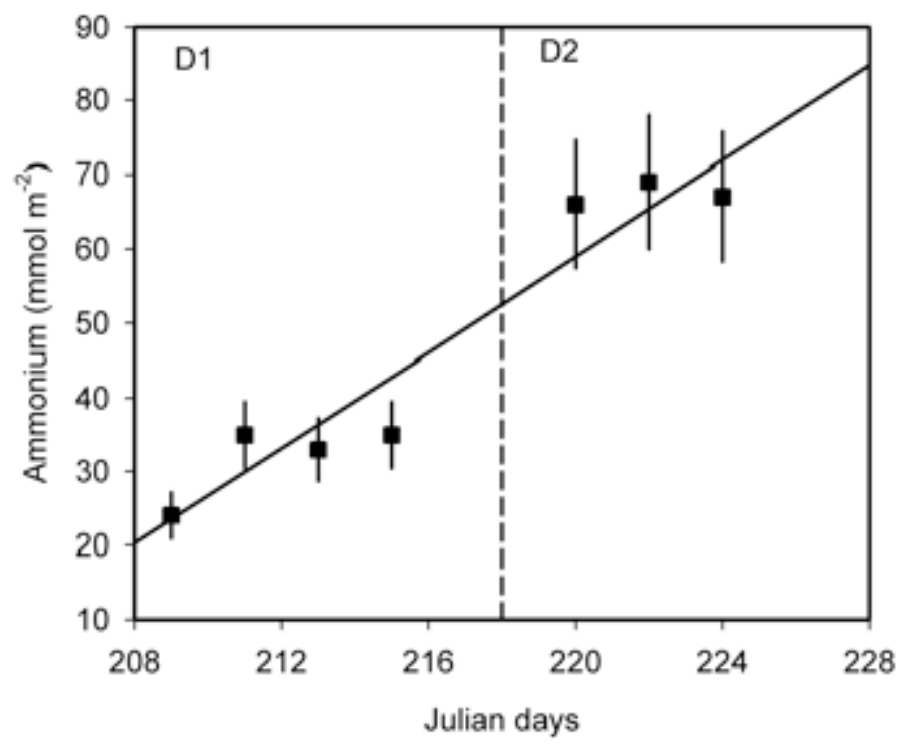

Figure 4: Depth-integrated ammonium stocks $(0-50 \mathrm{~m})$ during the trap deployments (D1 and D2). The errors bars represent the within-laboratory reproducibility (section 2.3). The slope $\mathrm{dNH}_{4} / \mathrm{dt}=3.2(\mathrm{SE}=0.4, \mathrm{p}<0.001) \mathrm{mmol} \mathrm{m}^{-2} \mathrm{~d}^{-1}$. SE: standard error. The $\mathrm{p}$ value is the probability that the slope does not differ from 0. 

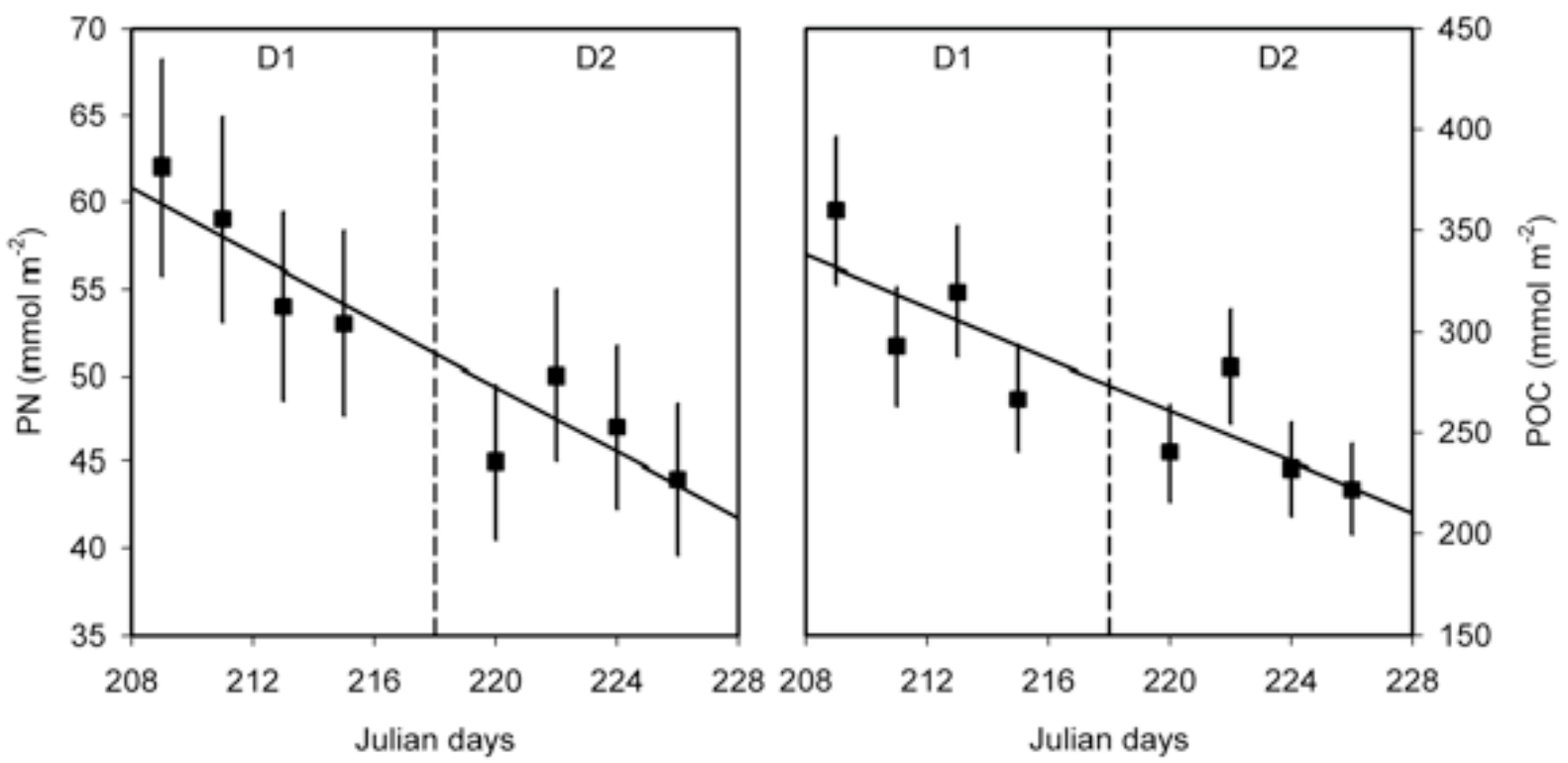

Figure 5: Depth-integrated POC and PN stocks $(0-50 \mathrm{~m})$ during the trap deployments (D1 and D2). The errors bars represent the within-laboratory reproducibility (section 2.3). Slopes $d P N / d t=-0.95(S E=0.15, p<0.001)$ and $d P O C / d t=-6.4(S E=1.5, p=$ 0.006) $\mathrm{mmol} \mathrm{m}^{-2} \mathrm{~d}^{-1}$. SE: standard error. The $\mathrm{p}$ value is the probability that the slope does not differ from 0 .

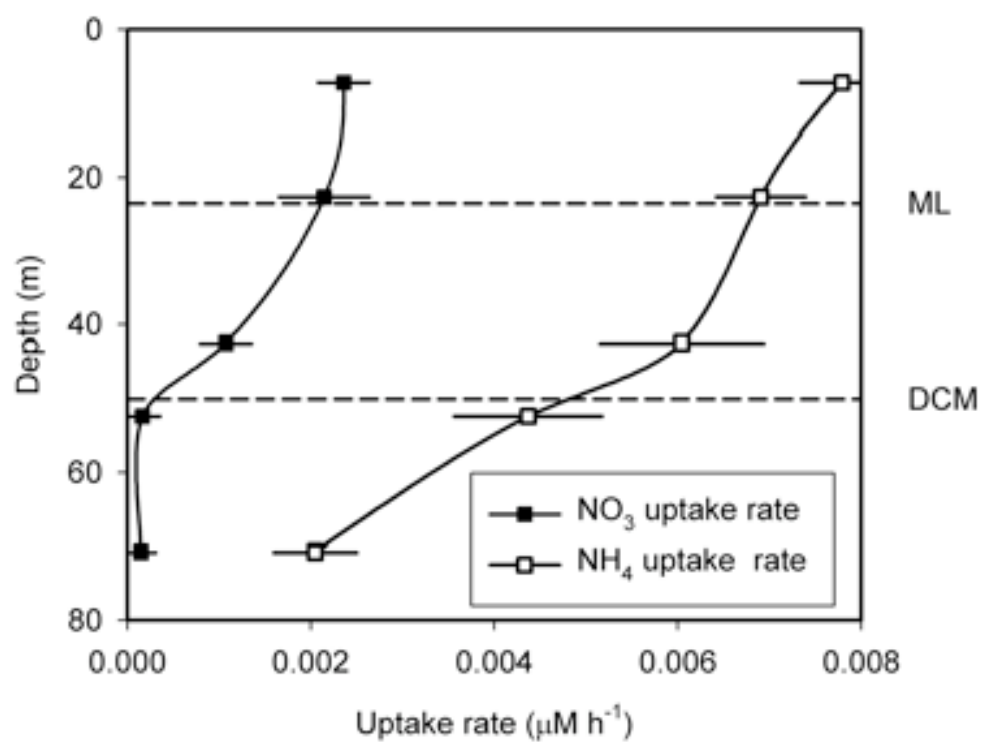

Figure 6: Averaged profiles $(n=8)$ of DIN uptake at K2. The error bars represent the sampling variability and are expressed as standard error of the mean. 

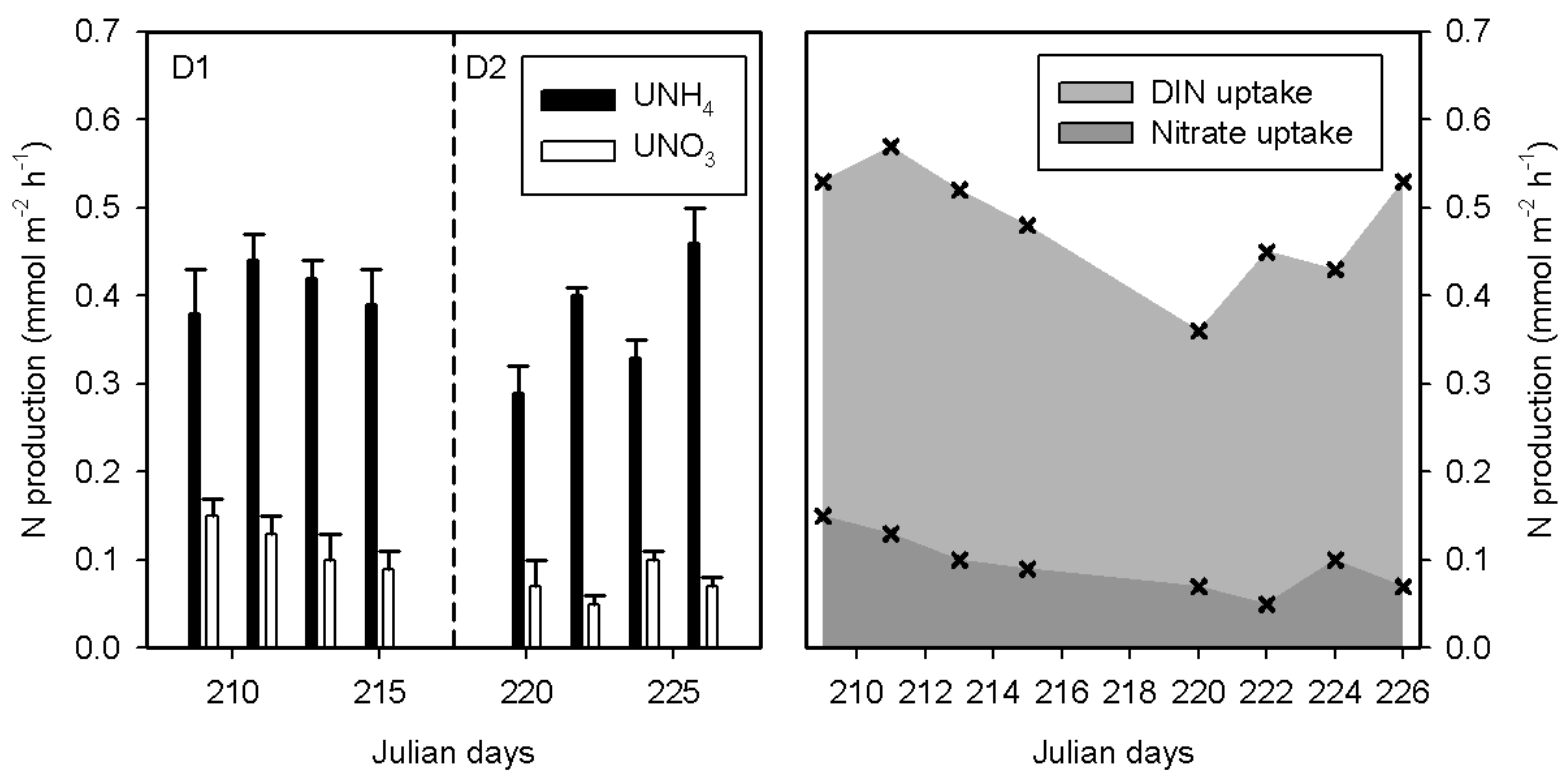

Figure 7: Depth-integrated nitrogen based production $(0-50 \mathrm{~m})$ during the trap deployments (D1 and D2). The error bars represent the uncertainty on rate calculations (propagation of random errors, section 2.8).
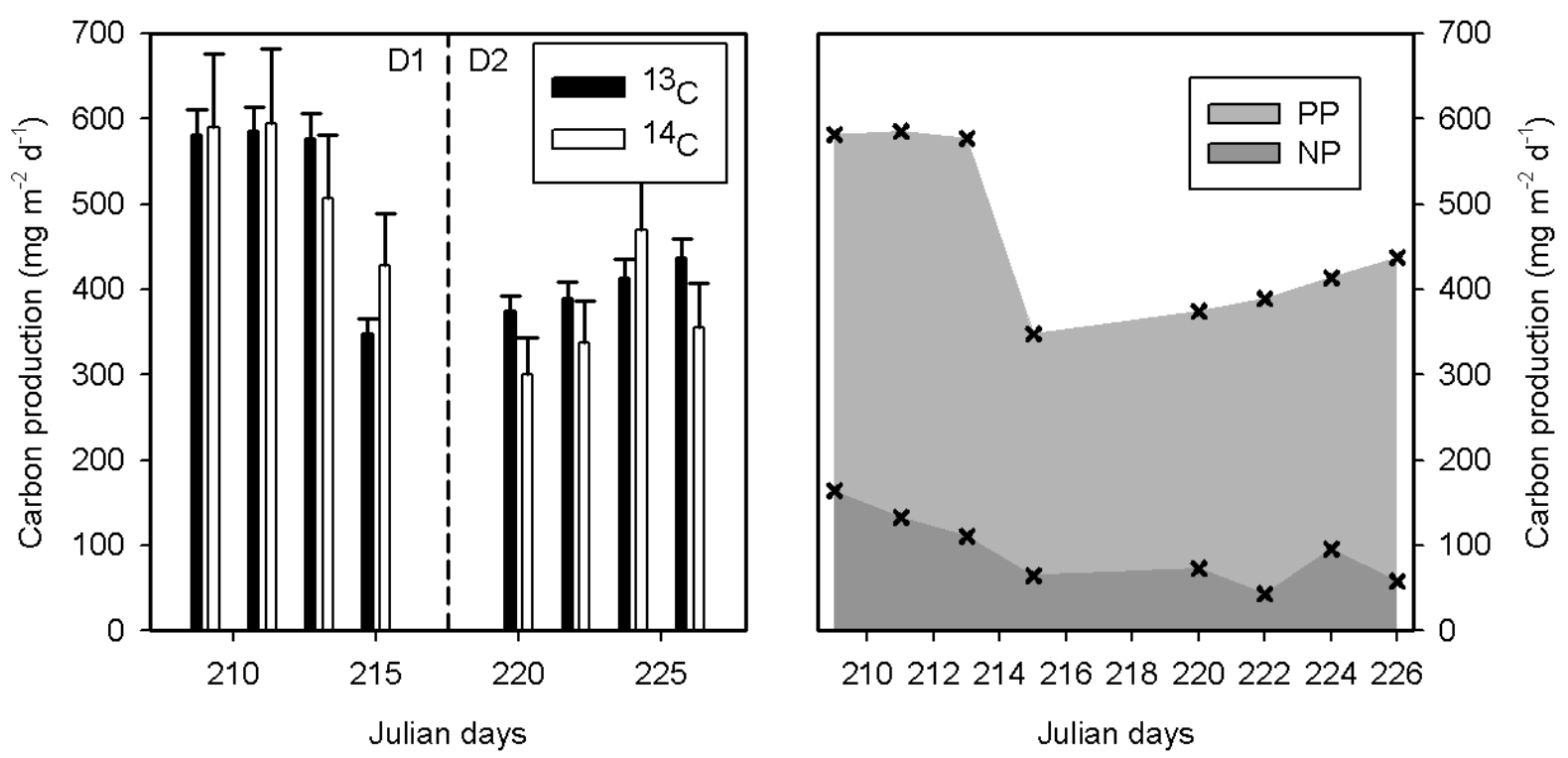

Figure 8: Depth-integrated primary and new productions $(0-50 \mathrm{~m})$ during the trap deployments (D1 and D2). The error bars represent the uncertainty on rate calculations (propagation of random errors, section 2.8). 


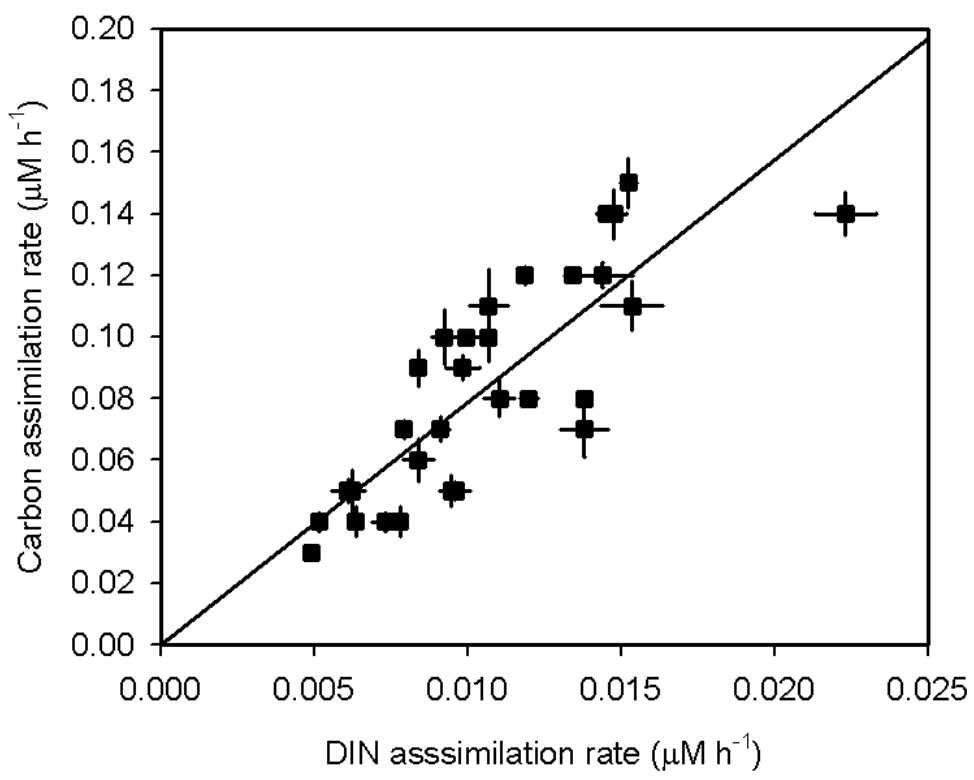

Figure 9: Relation between carbon and nitrate assimilation rates. The error bars represent the uncertainty on rate calculations (propagation of random errors, section 2.8). The slope UC/UDIN $=7.6(\mathrm{SE}=1.0, \mathrm{p}<0.001) . \mathrm{SE}$ : standard error. The $\mathrm{p}$ value is the probability that the slope does not differ from 0 .

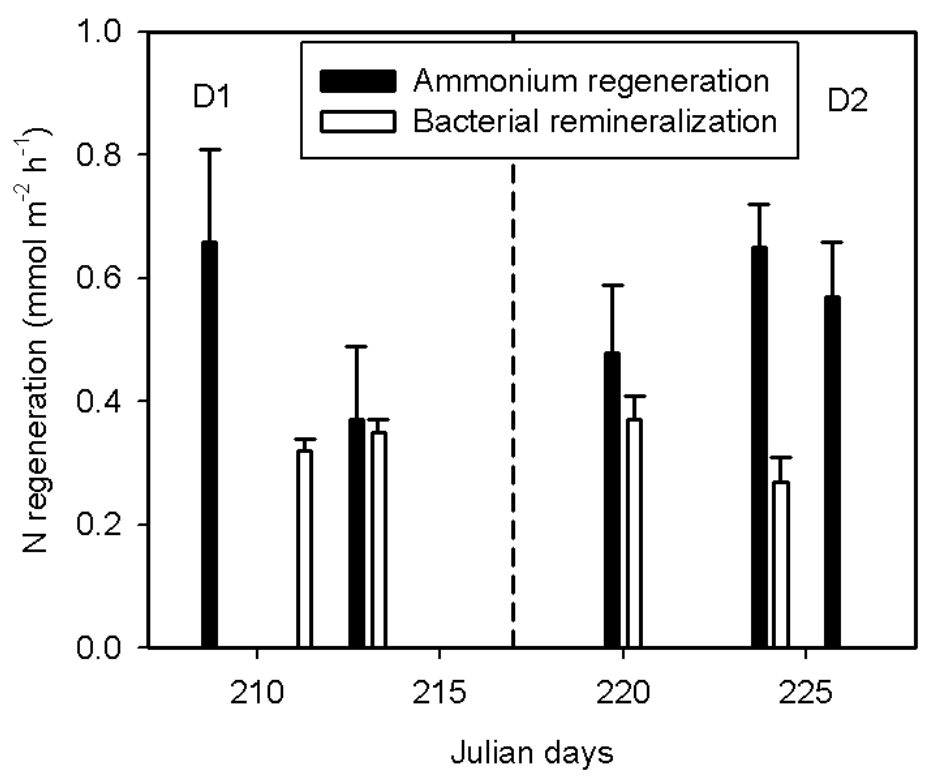

Figure 10: Depth-integrated ammonium production and bacterial mineralization (0 $50 \mathrm{~m}$ ) during the trap deployments (D1 and D2). The error bars represent the uncertainty on rate calculations (propagation of random errors, section 2.8 ). 


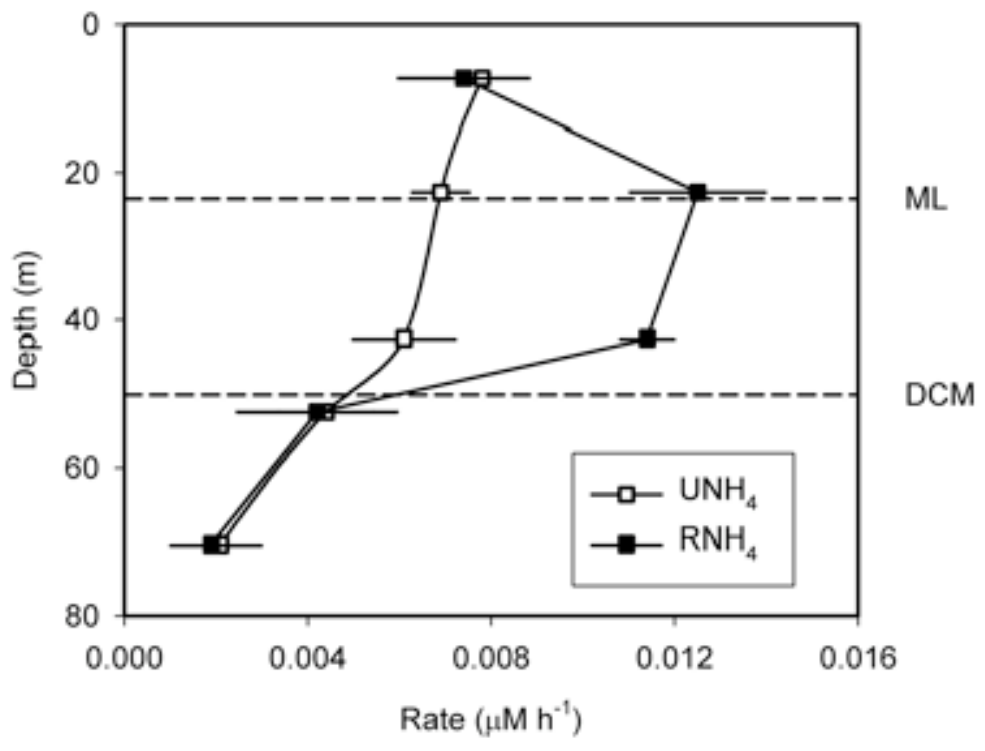

Figure 11: Averaged profiles $(n=5)$ of ammonium assimilation and regeneration at K2. The error bars represent the sampling variability and are expressed as standard error of the mean. 